\title{
Notes
}

\section{Why shall we consider the gender implications of biodiversity management? The role of women in the Mediterranean region}

\author{
ILARIA SISTO
}

Gender and Development Officer, FAO

\author{
MAURIZIO FURST \\ Gender and Development Specialist, FAO
}

\section{Introduction}

Women as farmers, livestock keepers, fishers and forest dwellers play vital - often overlooked - roles in natural resources use and management in the Mediterranean region. Women's exclusion from decision making bodies and unequal access to productive resources represent a missed opportunity in terms of sustainable management of available resources and economic development. Recent studies indicate that if men and women equally participate in the labour market, in the southern Mediterranean region the GDP could rise by $47 \%$ over the next decade, meaning an annual benefit from an economic impact of $€ 490$ billion (Woetzel et al., 2015).

The Director General of the Food and Agriculture Organization of the United Nations (FAO), José Graziano da Silva, at the fourth Regional conference on women's empowerment in the Euro-Mediterranean region stressed that rural women's contributions and leadership is crucial to feed the Mediterranean region's growing population and achieve sustainable food production: «By enabling rural women to reach their full potential, we can make food systems more inclusive, efficient and effective» (FAO 2018).

In the region women sustain such food systems by gathering wild plants for food, medicinal use, fuelwood and other purposes, acting as herbalists, tending home gardens, selecting, managing and storing seeds, managing crops, trees and small livestock, domesticating plants, participating in small-scale fisheries and aquaculture, and storing, preserving and processing foods after harvesting. They have a unique knowledge about local biodiversity, which is often passed from generation to generation (FAO, 2019; World Bank, FAO and IFAD, 2009).

Nevertheless, still too often women have less access than men to land and livestock, production inputs and services such as education, extension and credit, and are not represented in decision-making processes related to food and agriculture (Lehel 2018; World Bank, FAO and IFAD, 2009). 


\section{Gender differentiated local knowledge and division of labour}

To understand gender issues in plant and animal biodiversity we need to look at gender roles and relations as part of the overall livelihood systems that comprise farms and gardens, and common property resources such as pastures, forested lands and protected areas. While men take care of cash crops, women are traditionally involved in selecting, improving and adapting local plant varieties, seed exchange, management and saving. They grow and collect food, manage and use natural resources to fulfill the daily needs of their household (crops, tree products, wild and domesticated animals). In their home gardens - which are important experimental plots to for diverse wild plants and indigenous species - women grow traditional varieties of vegetables, herbs, spices used for nutritious, medicinal and culinary purposes.

Development intervention must build on gender roles and gaps. The project for Enhancing Gender Mainstreaming in sustainable rural development and food Security (GEMAISA) is implemented in Egypt, Jordan, Lebanon, Morocco, Palestine and Tunisia to empower rural women, by promoting natural resources management, food security, economic empowerment, equal access to resources and capacity building of partner institutions (Quagliariello, 2018).

Gender differentiated local knowledge systems play a decisive role in ecosystems conservation and management and improvement of genetic resources for food and agriculture. This knowledge, along with their particular roles in the economy, influences women's management strategies and priorities, often different from those of men. Women may prioritize crop characteristics, such as cooking time or preservability, overlooked by men, who are more concerned about marketability and yield (FAO, 2019). The decision of what to conserve depends on the know-how and the perception of men and women of what is most useful to the household and local community.

Such gender differentiated natural resource management knowledge and strategies were also confirmed by several countries during the preparation of The State of the World's Biodiversity for Food and Agriculture published in 2019. Algeria reports that the traditional knowledge regarding wild plants, their culinary, medical and aromatic uses and their conservation and related know-hows are mainly kept by women, who gather them with their children; while Lebanon highlights how women are well aware of diversity importance in their gardens and surrounding areas for family consumption and ornamental purposes (FAO, 2017).

Increasing attention is also given to the value of neglected and underutilized crops, the 'so-called 'orphan' crops, affirming what local communities have known for generations. Yet these crops can increase food production diversification, adding new species to our diets and particular nutrients, besides their economic and environmental benefits. Having a larger number of species to choose in a crop rotation system provides farmers with more sustainable production systems, disrupting the cycle of some pests and diseases, reducing infestations (FAO, 2019).

In this context, UN Women supports women seed growers in Morocco in safeguarding and use of biodiversity and ecosystem services, and created the network "Women seed growers" to promote local varieties (FAO, 2017). In 2016 women launched the "Seed Caravan" to share seeds and expertise, and raise awareness on the impacts of climate change 
(UN Women, 2016). Moreover, the Conservation of Medicinal and Herbal Plants project in Jordan targeted women's organizations to improve their awareness and knowledge on the conservation and sustainable management of medicinal plants, supported "conservation through cultivation" of plant species and facilitated their access to microcredit and participation in growers' and producers' organizations (FAO, 2019).

Women are primary collectors of wild foods that provide important micronutrients for the diet and can be essential for the household survival in case of food shortages. Spain and Lebanon highlighted the fact that rural women play a major role in maintaining and perpetuating the traditional knowledge about wild foods and forest products (FAO, 2017).

Through experience, innovation and experimentation, women act as real "scientists" and decision-makers in selecting and improving animal and plant genetic resources, which are crucial for biodiversity to ensure sustainable agriculture and food systems. The local knowledge is highly sophisticated and traditionally shared between generations. However, there is increasing concerns that local knowledge is disappearing, with the risk that this information is not passed to the next generation, with consequent erosion of plant diversity, family food security and nutrition.

Increasing recognition is given to women's role in natural resources management by the Convention on Biological Diversity and the Global Plans of Action, and the International Treaty on Plant genetic Resources. By recognizing at technical and institutional levels the relationship between biodiversity and the responsibilities and rights of men and women, we can address their specific interests and demands and increase their representation at policy and decision making levels.

\section{Women as drivers of change in the management of natural resources}

Several socio-economic and environmental changes transform women's roles in the management of natural resources and biodiversity and alter the traditional divisions of labour between men and women. The factors highlighted range from climate change, migrations, urbanization, and improved access to education to increasing demand for products typically produced by women (FAO, 2019). At times, women's participation in specific activities has increased by weakening sociocultural barriers.

Women's traditional roles in natural resources management make them particularly vulnerable to climate change in the south and eastern Mediterranean region, where they face a "double injustice" as they rely on rain fed systems and face structural barriers and limited diversification options reducing their adaptation capacity to climate change (Braham 2018; Lehel, 2018). Jordan, for instance, reports that climate change likely reduces the wild food availability adding on the burden on women, who traditionally collect wild foods, as they might need to walk longer distances to find them. Some countries note women's vulnerability to natural disasters such as droughts and hurricanes (FAO, 2017). Nevertheless women use their knowledge of ecosystems, skills and abilities and networks to protect their households and communities against climatic shocks (Lehel, 2018).

Lebanon states that main drivers affecting women's involvement in biodiversity maintenance and use for food and agriculture include changes in lifestyle, migration from rural areas to cities, economic and socio-political factors and the recent flow of Syrian refugees increasing women's involvement in agricultural activities (FAO, 2017). 
Gender is a determining factor of climate migrant's needs affecting the household vulnerability and resilience. Within the different flows of migration across and within the Mediterranean, women, boys and girls are the majority of the left behinds (Braham, 2018). In the southern Mediterranean region there are cases of rural depopulation, fueled by outmigration to neighbouring or distant cities or other countries, leading to women's increased involvement in managing agricultural holdings (FAO, 2019). A study conducted within the FAO Rural Youth Migration (RYM) project in Tunisia found that households with migrant members have higher access to social security and are increasingly feminized, due to male migration. Women in these households have a higher participation in the labour market, compared with women from households with no migrants; nevertheless, female unemployment remains high (Zuccotti et al., 2018).

\section{Obstacles and opportunities}

Despite their key role as biodiversity keepers and in household nutrition, women face structural barriers as they have less access to land and water, production inputs and services and are underrepresented in decision-making processes related to natural resources management (Lehel, 2018; World Bank, FAO and IFAD, 2009). Issues to consider to overcome barriers to rural women's empowerment in development interventions:

Labour saving technologies: Due to the double burden of household chores and engagement in agriculture, women face time poverty and have unpleasant tasks. For example, in poorer households, donkeys, mules and camels are used to carry water and fuelwood, which would otherwise be done by women. Raising locally adapted species, varieties and breeds of crops, livestock, trees or fish can be less demanding in terms of labour than raising their exotic counterparts. These labour-sparing characteristics can make locally adapted genetic resources important for women, who often spend a lot of time on child-rearing and domestic activities (FAO, 2019).

Access to productive inputs: Several countries also acknowledge that women's participation in BFA management is constrained by lack of access to external inputs and productive resources. Jordan notes that poverty increasing levels have led to more women involved in wild-food collection. Due to modern technologies and perceptions, women have often lost influence over production and access to resources compared to men, who benefit more from extension services and can buy seeds, fertilizers and required technologies. In this way women lose also their status and self-determination and are not compensated in any way.

Decision making: Several countries also note that women's decision-making power in the management and conservation of BFA is constrained by stereotypes and socio-economic barriers, resulting in their under-representation in decision-making.

Access to land and water: We also need to analyze land tenure arrangements and organizational structures of different user groups (by gender, age, class, ethnicity and occupation) and the uneven power relations in accessing and controlling land, animal and plant resources that influence men's and women's capacities and incentives to conserve agro-biodiversity. Unsustainable management practices and changes in land and water use threaten livelihoods, affecting common-property resources for fuelwood, fodder and wild foods, upon which women are often disproportionately dependent. 
Access to markets: men usually sell their crops in national or export markets, whereas women in local markets where there is a demand for traditional varieties. Trade can improve their livelihoods by providing an income and incentive to manage, use and conserve local indigenous plants. However, women face more challenges in accessing and benefitting from markets. Globalization can give small producers the opportunity to target niche markets for fair trade or organic products, protecting biodiversity.

More efforts are needed to address women's barriers and provide them with equal provision of rural services and infrastructure, representation in local institutions and governance mechanisms and include them in decision-making within the households and communities.

\section{References}

Braham M., 2018. Gender and climate induced migrations in the Mediterranean Region. In: CIHEAM, UfM, Strenghtening the role of women in rural and agricultural areas. Obstacles and opportunities. Watch Letter, CIHEAM-Union for the Mediterranean, 40.

Chocholata L., Allara M., Impiglia A., Tagliati E., 2016. Farmer Field Schools and Empowerment. Community empowerment, social inclusion and gender equality, experience from Jordan and Tunisia. Rome: FAO, pp. 16.

CIHEAM, UfM, 2018. Strenghtening the role of women in rural and agricultural areas. Obstacles and opportunities. Watch Letter, CIHEAM-Union for the Mediterranean, 40.

FAO, 2016. Palestinian Womens'Associations and Agricultural Value Chains. Rural employment. Case Studies Series (2). Rome: FAO, pp. 18.

FAO, 2017. Country Reports prepared by member states for the preparation of The State of the World's Biodiversity for Food and Agriculture. Available online at: http://www.fao.org/cgrfa/top$\mathrm{ics} /$ biodiversity/sowbfa/countryreports/en/ (last accessed: April 15 $5^{\text {th }} 2019$ ).

FAO, 2018. FAO Director-General's message at Women4Mediterranean Conference. Available online at: http://www.fao.org/director-general/newsroom/news/detail/en/c/1156981/ (last accessed: April 15 $5^{\text {th }}$ 2019).

FAO, 2019. The State of the World's Biodiversity for Food and Agriculture, ed. by Bélanger J. and Pilling D. Rome: FAO Commission on Genetic Resources for Food and Agriculture Assessments, pp. 572.

Lehel S., 2018. FAO's Commitment to empowering rural women in the Near East and North Africa region. In: CIHEAM, UfM: Strenghtening the role of women in rural and agricultural areas. Obstacles and opportunities. Watch Letter, CIHEAM-Union for the Mediterranean, 40.

Quagliariello R., 2018. In: CIHEAM, UfM, Strenghtening the role of women in rural and agricultural areas. Obstacles and opportunities. Watch Letter, CIHEAM-Union for the Mediterranean, 40.

UN Women, 2016. Moroccan women take on climate change. Available at: http://www.unwomen. org/en/digital-library/videos?videoid=A2Q-8i3aeOA (last accessed: April 15 ${ }^{\text {th }}$ 2019).

Woetzel J., Madgavkar A., Ellingrud K., Labaye E., Devillard S., Kutcher E., Manyika J., Dobbs R., and Krishnan M., 2015. How advancing women's equality can add \$12 trillion to global growth. New York: McKinsey \& Company.

World Bank, FAO \& IFAD, 2009. Gender in agriculture sourcebook. Washington, DC: The World Bank, pp. 764.

Zuccotti C.V., Geddes A., Bacchi A., Nori M., Stojanov R., 2018. Drivers and patterns of rural youth migration and its impact on food security and rural livelihoods in Tunisia. Rome: FAO, pp. 56. 